\title{
Dinamika Komunikasi Politik Dalam Pilkada Di Indonesia
}

\author{
Samsul Rani \\ UIN Antasari Banjarmasin
}

\begin{abstract}
The phenomenon of 2018 regional elections can be seen in the selection of candidate pairs, party coalitions, and the delivery of political messages conveyed by political parties and candidate pairs, which have given birth to a variety of maneuvers, rivalries in the formulation of political strategies to support or subdue each other. This communication constellation has shaped the dynamics of Pilkada political communication in Indonesia. Of the 171 regions that held elections, 16 of them had a single candidate whose average candidate pair was supported by 6 to 12 political parties. The phenomenon of mutually changing pairs of candidates or revoking support has become a public concern in the elections. This can be caused by unfulfilled supporting requirements, lobbying from other parties, low electability, legal cases, and political dowry. The role of the mass media in Pilkada is very good, because the mass media has become an independent and transparent party, the news related to the Pilkada is published based on facts and data, it does not appear that mass media "fry" the issues so that the condition of the community is more conducive and the elections run safely.
\end{abstract}

Keywords: political communication; local election; political parties

\section{Pendahuluan}

Komisi Pemilihan Umum (KPU) telah melaksanakan Pemilihan Kepala Daerah (Pilkada) secara serentak tahun 
2018. Pilkada serentak gelombang pertama ini telah diikuti oleh 171 pemilihan kepala daerah di seluruh Indonesia, yang terdiri dari 17 provinsi, 39 kota, dan 115 kabupaten (Kemendagri.go.id). Pemilu serentak ini dimaksudkan untuk mewujudkan pemilihan gubernur dan wakil gubernur, bupati dan wakil bupati, serta walikota dan wakil walikota yang demokratis.

Partai politik sebagai pengusung pasangan calon dalam Pilkada tentu melakukan komunikasi politik yang efektif dan efisien sehingga diharapkan mampu menampilkan kesan dan pesan politik kepada partai koalisi maupun konstituen, sehingga menjadi pendukung pasangan calon tersebut. Nimmo (2004:156) berpendapat bahwa komunikasi politik (political communication) adalah komunikasi yang melibatkan pesanpesan politik dan aktor-aktor politik, atau berkaitan dengan kekuasaan, pemerintahan, dan kebijakan pemerintah. Cangara (2009:35) berpendapat bahwa komunikasi politik adalah sebuah proses pengoperasian lambang-lambang atau simbolsimbol komunikasi yang berisi pesan-pesan politik dari seseorang atau kelompok kepada orang lain dengan tujuan untuk membuka wawasan atau cara berfikir, serta mempengaruhi sikap dan tingkah laku khalayak yang menjadi target politik.

Sehingga partai politik memerlukan strategi komunikasi politik baik dan elegan untuk bertarung di arena Pilkada. Komunikasi politik yang dilakukan partai politik harus menjadi rangsangan politik yang dapat menggugah ketertarikan dan simpati kepada calon kepala daerah yang diusungnya untuk itu diperlukan sebuah strategi komunikasi. 
Strategi komunikasi politik merupakan tentang bagaimana proses komunikasi yang terjadi di dalam pemenangan dalam satu pertarungan politik oleh partai politik, atau secara langsung, oleh calon pimpinan daerah, yang menghendaki kekuasaan dan pengaruh sebesar-besarnya di tengah-tengah masyarakat sebagai konstituennya (Zein, 2008:99). Faktorfaktor dari proses komunikasi politik meliputi: komunikator politik, pesan politik, saluran atau media politik, sasaran atau target politik, dan pengaruh atau efek komunikasi politik (Zein, 2008:109).

Strategi komunikasi politik tidak terlepas dari pembuatan dan penyampaian pesan politik, dengan demikian komunikasi politik bukan hanya diperankan partai politik tetapi juga sangat penting untuk dikuasai para calon pemimpin dalam Pilkada, khususnya dalam penyampaian visi, misi, ide dan gagasan kepada masyarakat. Komunikasi politik sangat dibutuhkan untuk memenangkan simpati masyarakat dalam ajang Pilkada, terutama saat pelaksanaan debat publik.

Sehubungan dengan itu banyak terjadi fenomena dalam ajang Pilkada serentak yang dilakukan pada tahun 2018, fenomena ini dapat dilihat pada pemilihan pasangan calon, koalisi partai, dan penyampaian pesan politik yang disampaikan oleh partai politik maupun pasangan calon, yang telah melahirkan beragam manuver, rivalitas dalam perumusan strategi politik untuk saling mendukung atau menundukkan. Konstelasi komunikasi ini telah membentuk dinamika komunikasi politik Pilkada di Indonesia. 


\section{Pembahasan}

\section{Komunikasi Politik Dalam Koalisi}

Koalisi partai dalam pengusungan pasangan calon pada Pilkada 2018 pada awalnya diperkirakan akan diwarnai pertarungan berbasis politik identitas atau primordial untuk mengulang kesuksesan seperti Pilkada DKI 2017, ternyata hal tersebut tidak terjadi. Walaupun pada dasarnya pimpinan partai politik Gerindra, PKS, dan PAN melakukan pertemuan intensif untuk menentukan calon gubernur dan wakil gubernur untuk beberapa provinsi.

Berbagai peta koalisi yang mengusung pasangan calon, hanya sedikit kesamaan partai pendukung pasangan calon seperti pada Pilkada DKI 2017, dan tidak mengikat koalisi partai di tingkat lokal, baik ditingkat kabupaten maupun kota. Walaupun masih ada sejumlah partai yang tetap menganggap penting sebuah kesamaan ideologi dan berusaha menanamkannya sejak proses awal perekrutan calon kepala daerah.

Ketiadaan kesamaan ideologi sebagai syarat dalam pengusungan pasangan calon seperti pengelompokan agama maupun kelompok nasionalis, justru lebih baik untuk menghindari terjadinya konflik SARA. Partai politik dalam menetapkan pasangan calon pada Pilkada 2018 ternyata lebih memperhatikan dimensi elektorat, elektabilitas, serta kontribusi pasangan calon dalam ruang politik lokal. Hal inilah yang menyebabkan perbedaan yang sangat signifikan jumlah koalisi partai dan ideologi dalam satu pasangan calon, baik ditingkat provinsi, kabupaten, dan kota.

Tabel 1. Partai Politik Pengusung Pasangan Calon Kepala Daerah 


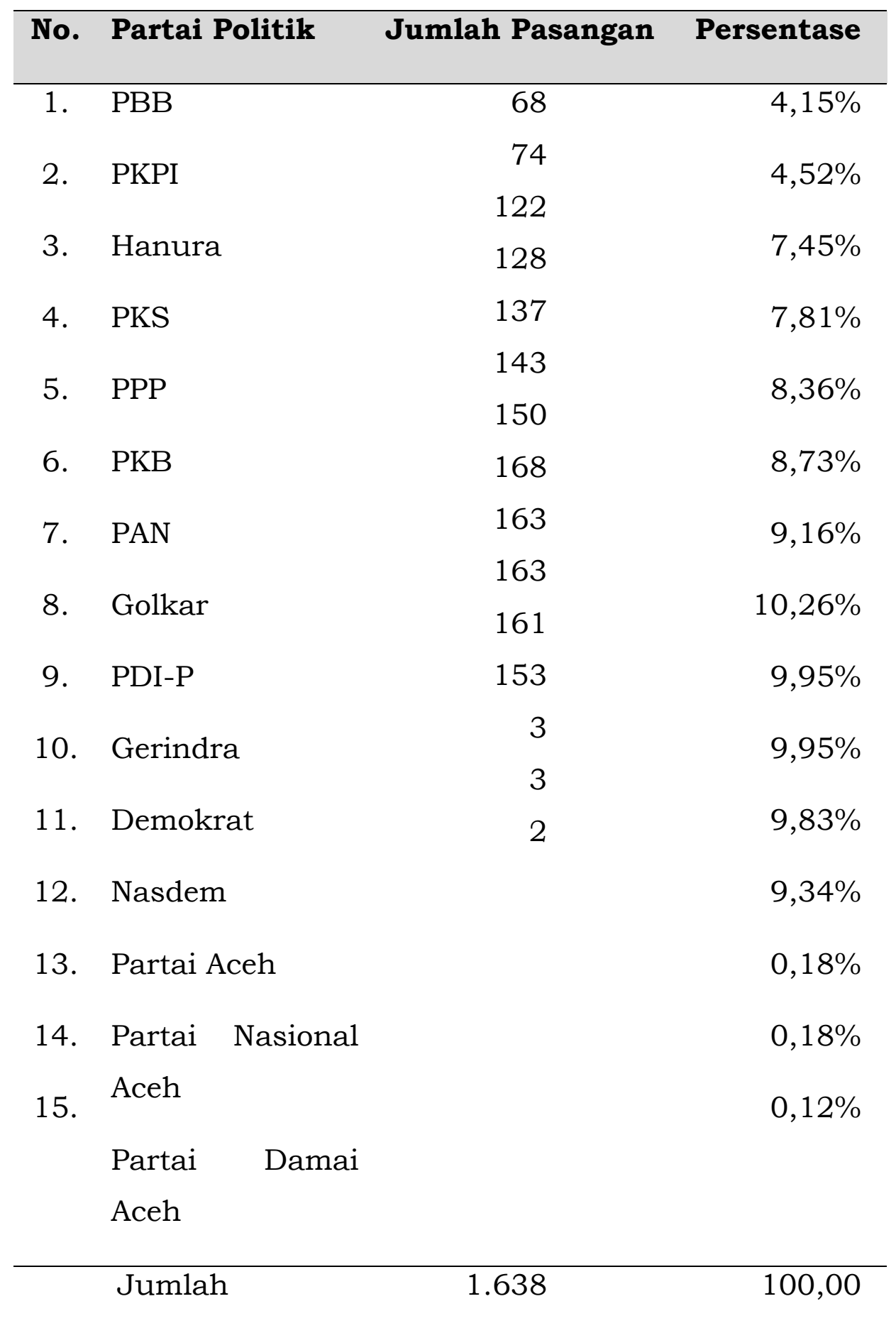

Sumber: Kompas.com, 2018.

Pada tabel di atas dapat dilihat bahwa terdapat 1.638 pasangan calon dalam pemilihan kepala daerah untuk 171 wilayah pemilihan 
baik ditingkat provinsi, kabupaten, dan kota. Data tersebut menunjukan Partai Golkar, PDI-P, Gerindra, dan Demokrat paling banyak mengusung pasangan calon, dibandingkan dengan partai lainnya. Dari 171 wilayah pemilihan terdapat 16 daerah pemilihan yang hanya memiliki pasangan calon tunggal yaitu, untuk Pilkada kabupaten pada daerah Deli Serdang, Padang Lawas, Pasuruan, Lebak, Tanggerang, Tapin, Minahasa Tenggara, Bone, Enrekang, Mamasa, Mamberamo Tengah, Puncak, dan Jayawijaya. Sedangkan untuk Pilakda Kota pada wilayah Prabumulih, Tangerang, Makassar. Pada 16 daerah yang memiliki calon tunggal, pasangan calon rata-rata didukung oleh 6 sampai 12 partai politik. Sedangkan pada Pilkada Kabupaten Aceh Selatan memiliki pasangan calon paling banyak yaitu 7 pasangan.

Fenomena koalisi partai tersebut menunjukan dinamika komunikasi politik yang dinamis. Pada partai yang mengusung banyak pasangan calon dapat dipastikan komunikasi politik internal dan eksternalnya memiliki komunikasi politik yang baik. Hal ini juga dilihat pada banyaknya wilayah pemilihan yang hanya memiliki calon tunggal karena pasangan calon didukung oleh banyak partai politik. Tetapi banyaknya pasangan calon yang muncul dari jalur perseorangan (independent) sebanyak 83 pasangan (15,9\%) dari 520 pasangan calon yang ikut dalam Pilkada 2018, menunjukan bahwa komunikasi partai politik belum dapat dikatakan optimal, ditambah lagi dengan pasangan calon tunggal yang didukung partai politik kalah dalam Pilkada padahal hanya melawan "kotak kosong" seperti yang terjadi pada Pilkada Kota Makassar. Banyaknya jumlah pasangan dalam Pilkada pada suatu daerah juga dapat dikatakan merupakan kegagalan komunikasi politik partai untuk merangkul kandidat. Hal 
ini menandakan bukan hanya belum optimalnya komunikasi di jalur antar partai tetapi juga komunikasi politik kepada konstituen.

Tabel 2. Jalur Pengusulan Pasangan Calon Kepala Daerah

\begin{tabular}{|c|c|c|c|}
\hline No. & $\begin{array}{l}\text { Klasifikasi } \\
\text { Daerah }\end{array}$ & $\begin{array}{l}\text { Jalur Pengusulan } \\
\text { Calon }\end{array}$ & Jumlah \\
\hline 1. & $\begin{array}{l}\text { Provinsi } \\
\text { (55 Pasangan) }\end{array}$ & $\begin{array}{l}\text { a. Jalur Partai } \\
\text { Politik } \\
\text { b. Jalur } \\
\text { Perseorangan }\end{array}$ & 52 \\
\hline 2. & $\begin{array}{l}\text { Kabupaten } \\
\text { (344 Pasangan) }\end{array}$ & $\begin{array}{l}\text { a. Jalur Partai } \\
\text { Politik } \\
\text { b. Jalur }\end{array}$ & $\begin{array}{r}283 \\
61\end{array}$ \\
\hline 3. & $\begin{array}{l}\text { Kota } \\
\text { (121 Pasangan) }\end{array}$ & $\begin{array}{l}\text { Perseorangan } \\
\text { a. Jalur Partai } \\
\text { Politik } \\
\text { b. Jalur } \\
\text { Perseorangan }\end{array}$ & $\begin{array}{r}102 \\
19\end{array}$ \\
\hline & & Total & 520 \\
\hline
\end{tabular}

Isu gender juga merupakan masalah dalam komunikasi politik antar partai dalam menentukan pasangan calon, terlebih apakah memiliki nilai jual atau tidak, mengingat masih ada kelompok partai yang memiliki ideologi yang sensitif dengan isu kepemimpinan wanita dalam Pilkada begitu juga dengan daerah pemilihannya. Berdasarkan 
data Pilkada 2018 terdapat 104 (9,13\%) pasangan calon yang berjenis kelamin wanita, hal ini menunjukan perkembangan yang sangat signifikan dalam isu gender calon kepala daerah atau wakil yang berjenis kelamin wanita dibandingkan dengan Pilkada tahun tahun sebelumnya.

Tabel 3. Jenis Kelamin Pasangan Calon Kepala Daerah

\begin{tabular}{cclc}
\hline No. & Klasifikasi Daerah & Jenis Kelamin & Jumlah \\
\hline 1. & Provinsi & a. Pria & 107 \\
& & b. Wanita & 7
\end{tabular}

a. Pria

2. Kabupaten

b. Wanita

688

a. Pria

b. Wanita

3. Kota

Sumber: Kompas.com, 2018.

\section{Komunikasi Politik Pasangan Calon}

Dalam banyak kasus lahirnya pasangan calon kepala daerah dan wakil kepala daerah tidak serta merta begitu saja ada, mereka lahir lewat proses komunikasi politik yang alot, baik di antara partai politik 
maupun di antara kandidat. Bahkan, jika ditelusuri secara saksama, jarang sekali pasangan calon kepala daerah dan wakil kepala daerah yang bergabung sejak awal. Kendati ada karena dipayungi oleh satu bendera partai, mereka notabene kalah dalam "pertarungan" (Hkikmat, 2017:42). Gonta ganti pasangan calon dan mencabut dukungan pasangan calon bukan hal yang tabu dalam dunia politik, walaupun pencabutan dukungan tersebut dimenit menit terakhir pendaftaran pasangan calon. Hal ini dapat disebabkan oleh 1). Syarat kursi pengusung yang tidak terpenuhi, 2). Lobby dari partai lain, 3). Elektabilitas, 4). Kasus hukum, maupun 5). Mahar politik. Skrzypinski (dalam Boicu, 2017:248) berpendapat bahwa In the case of parties, a signifcant and often dominant part of the candidates were new politicians, and the main criterion for their recruitment was their high level of commitment, ideological identifcation and good personal relations with central or regional political leaders.

Pada konteks komunikasi, komunikasi politik merupakan aksesibilitas bagi para calon kepala daerah untuk melakukan komunikasi politik yang efektif dengan rakyat pemilih. Aksesbilitas politik akan melahirkan tingkat elektabilitas politik, yang pada akhirnya tingkat aksebilitas politik yang tinggi berpotensi besar akan melahirkan dukungan partai politik untuk meminang atau mendukung pasangan calon. Hal ini disebabkan partai politik maupun koalisi partai tidak menginginkan pasangan calon yang tidak mempunyai "nilai jual" karena dapat mempengaruhi suara partai pada Pemilu berikutnya baik pemilihan legislatif maupun pemilihan presiden, oleh karena itu partai politik biasanya melakukan mapping politik terhadap calon yang akan didukungnya yang berpotensi memenangkan Pilkada. 
Fenomena gonta ganti pasangan calon atau mencabut dukungan yang paling menjadi perhatian publik pada Pilkada 2018 adalah kasus Pilkada Provinsi Jawa Barat, yang mana Partai Golkar mencabut dukungan untuk Ridwan Kamil di Pemilihan Gubernur Jawa Barat dan mengalihkan dukungan ke Dedi Mulyadi, sedangkan Deddy Mizwar dengan elektabilitas terkuat kedua di daerah itu dua parpol pengusungnya PKS dan PAN menarik dukungan karena ada lobi dari Partai Gerindra, yang akhirnya ketiga partai tersebut mengusung pasangan calon lain. Kasus lain yang juga terekspos ke publik adalah adanya isu mahar politik yang dituduhkan kepada pada Partai Gerindra, walaupun isu tersebut sudah ditepis bahwa bukan mahar pencalonan yang diminta, tetapi kemampuan keuangan calon yang diusung untuk membayar saksi di TPS.

Pada dasarnya salah satu pertimbangan partai pengusung dalam mendukung pasangan calon adalah track record, salah satunya adalah karakteristik pekerjaan atau posisi yang dimiliki oleh pasangan calon. Pada Pilkada 2018 peserta Pemilu memiliki karakteristik pekerjaan yang sangat beragam, yang pada akhirnya menimbulkan komunikasi politik yang beragam juga, seperti yang terlihat pada tabel berikut ini:

Tabel 4. Peserta Pilkada Berdasarkan Pekerjaan

\begin{tabular}{clrr}
\hline No. & Pekerjaan & Frekuensi & Persentase \\
\hline 1. & Pegawai BUMN/BUMD & 10 & $1,60 \%$ \\
2. & Tentara & 6 & $0,96 \%$ \\
3. & Polisi & 8 & $1,28 \%$ \\
4. & PNS & 153 & $24,44 \%$ \\
& & 1 & \\
\hline
\end{tabular}




\begin{tabular}{clrr}
\hline 5. & Anggota KPU/Bawaslu & 4 & $0,16 \%$ \\
6. & Pejabat Bupati & 6 & $0,16 \%$ \\
7. & Kepala Desa & 45 & $0,64 \%$ \\
8. & Anggota DPD & 148 & $0,96 \%$ \\
9. & Anggota DPRD Provinsi & 6 & $7,19 \%$ \\
10. & Anggota & 9 & $23,64 \%$ \\
11. & Kabupaten/Kota & 35 & $3,83 \%$ \\
12. & Anggota DPR & 25 & $0,96 \%$ \\
13. & Gubernur & 57 & $1,44 \%$ \\
14. & Wakil Gubernur & & $5,59 \%$ \\
15. & Walikota & & $3,99 \%$ \\
16. & Wakil Walikota & & $14,06 \%$ \\
17. & Bupati & & $9,11 \%$
\end{tabular}

Wakil Bupati

\begin{tabular}{lll}
\hline Jumlah & 626 & 100,00
\end{tabular}

Sumber: Kompas.com, 2018.

Pada tabel tersebut terlihat bahwa sebagian besar peserta Pilkada tidak asing dengan dengan pemilihan umum, hanya 28,43\% peserta Pilkada yang tidak pernah terlibat dalam politik praktis pemilihan umum. Data pada tabel tersebut cukup menarik karena 24,44\% peserta Pilkada adalah dari golongan PNS atau birokrat yang sebelum 
tidak pernah terlibat atau ikut dalam pemilihan umum. Sedangkan peserta Pilkada dari Anggota DPRD Kabupaten/Kota merupakan peserta yang memiliki karakteristik terbanyak kedua yang mengikuti Pilkada serempak 2018.

Bagi peserta Pilkada dari kalangan BUMN/BUMD, Tentara, Polisi, PNS, dan Anggota KPU/Bawaslu, komunikasi politik yang dilakukan untuk memperoleh dukungan partai atau koalisi partai adalah sesuatu yang cukup sulit, mengingat mereka harus memperoleh dan menaikan elektabilitas dimasyarakat sehingga terjaring dalam mapping politik yang dilakukan partai baik melalui analisis di atas kertas maupun survey. Dalam hal tersebut maka calon pasangan yang mencari dukungan partai politik akan melalakukan berbagai macam cara, seperti yang disampaikan Popkin (dalam Kiyohara, 2018:79) bahwa "politicians are crowd-seekers, and changing media creates audiences, so they adopt the strategy of media change. This means that politicians have strong motivation to optimize their campaign strategies and embrace new media environments.

\section{Komunikasi Politik Dalam Kampanye}

Sebagai aktor politik, calon kepala daerah dan wakil kepala daerah diberikan peran sebagaimana diatur dalam peraturan perundangan-undangan, beberapa panggung politik memberikan kesempatan kepada aktor politik; calon kepala daerah dan wakil kepala daerah untuk banyak berperan, bahkan menjadi peran utama dalam komunikasi politik. Fenomena komunikasi politik dalam strategi kampanye selalu dengan memberikan visi, misi, dan program kampanye yang sesuai dengan aspirasi, identifikasi masalah serta potensi dari rakyat sendiri berdasarkan hasil riset kampanye yang 
dilakukan oleh pasangan calon. Dinamika fenomena komunikasi politik menjadi semakin berkembang dengan dukungan dan kekuatan media massa dalam mewujudkan demokratisasi (Sulaiman, 2013:119).

Persoalan untuk mengemas pesan politik dalam kampanye pemilu menjadi urusan yang sangat penting bagi partai politik dan calon yang maju bersamanya, agar makna pesan dapat diterima secara efektif oleh audiensnya. Huckfeldt (1995:107) berpendapat bahwa "Citizens obtain political information from a great many sources, politicians speeches, media reports, mass mailings, but they also obtain it from one another through various forms and means of social interaction. Not all information obtained through social interaction comes via the means of political discussion. Some of it comes from lapel pins, yard signs, and bumper stickers".

Pesan sebagai elemen kampanye diartikan sebagai pernyataan ringkas yang menyebutkan mengapa pemilih harus memilih seorang kandidat tertentu. Pesan adalah salah satu aspek terpenting dalam setiap kampanye politik. Dalam kampanye politik modern, pesan harus disusun dengan sangat hati-hati sebelum disebarkan dan menjadi konsumsi media dan publik (Kusuma Dan Hotman, 2008:25). Selain itu diperlukan strategi public relations politik dalam membentuk political branding. Menggunakan media, produksi pesan. Media yang dimaksud yaitu media sosial, media tatap muka, media format kecil, media luar ruang. Produksi pesan yakni menyusun dan membuat pesan sebaik mungkin serta memperhatikan isi pesan mana saja yang akan disampaikan baik lisan maupun tulisan (Wahyuni, 2018:12). Penggunaan teknologi media juga harus menjadi pertimbangan dalam kampanye, hal ini telah dilakukan oleh pasaangan calon dalam Pilkada 2018 walaupun mungkin belum secara maksimal dilaksanakan. 
Panagopoulus berpendapat bahwa "A wide range of technological developments, most notably although not exclusively the Internet, has transformed the landscape of modern political campaigns. Technology has increasingly been featured in political campaigns throughout the world in prominent and unprecedented ways. Campaigns have capitalized on advancements in technology to inform, target and mobilize voters" (Panagopoulus, 2009:1)

Kondisi Pilkada 2018 dilaksanakan dengan aman lancar, tidak terjadi gesekan antar kelompok, antar suku, dan sebagainya seperti Pilkada DKI Jakarta pada tahun 2017. Kampanye terbuka maupun kampanye tertutup dan juga program debat yang dilaksanakan KPU berjalan dengan lancar. Kampanye yang dilakukan bukan dengan mengeksplorasi kelemahan lawan atau pun dengan black campaign, tetapi dengan masing-masing punya justifikasi program, menawarkan program unggulan dan memperbaiki program yang ada, kemudian track record, termasuk menjelaskan tentang visi misi ke depannya. Pada dasarnya pengaturan pesan dalam komunikasi politik yang menyentuh kebutuhan masyarakat secara mendasar akan meningkatkan partisipasi masyarakat dalam kegiatan politik, khususnya pemilu dan membangun kredibilitas komunikator politik dengan partai politiknya secara positif (Susanto, 2013:171). Walaupun masih ada terlihat dalam program debat pasangan calon yang menyinggung masalah pribadi dalam acara debat yang dilaksanakan oleh KPU di televisi, seperti yang terjadi pada program debat calon gubernur Jawa Tengah, Sudirman Said menyinggung masalah kasus hukum E-KTP yang mana Ganjar Pranowo dijadikan sebagai saksi oleh KPK. Begitu juga dengan debat calon gubernur Jawa Barat, terdapat insiden ucapan dan kaus bertulis “2019 Ganti Presiden” yang 
diperlihatkan oleh pasangan calon (Paslon) pasangancalon SudrajatAhmad Syaikhu.

Peran media massa pada Pilkada 2018 sangat baik, karena media massa telah menjadi pihak independen dan transparan, berita-berita terkait Pilkada dipublikasikan berdasarkan fakta dan data, tidak terlihat media massa yang "menggoreng" isu yang ada sehingga kondisi masyarakat kian kondusif dan Pilkada berjalan aman. Belajar dari pilkada DKI Jakarta 2017, pihak media massa seperti para jurnalis dan media itu tidak dikendalikan oleh kepentingan para politisi, memihak pasangan calon maupun tim sukses. Media massa, terutama para jurnalis sudah tentunya memiliki kepercayaan dari rakyat, dan diharapkan memiliki kebudayaan untuk menjaga kredibilitas dan kepercayaan penuh dalam menjaga netralitas media massa ke depan.

\section{Simpulan}

Ketiadaan kesamaan ideologi sebagai syarat dalam pengusungan pasangan calon seperti pengelompokan agama maupun kelompok nasionalis, justru lebih baik untuk menghindari terjadinya konflik SARA. Partai politik dalam menetapkan pasangan calon pada Pilkada 2018 ternyata lebih memperhatikan dimensi elektorat, elektabilitas, serta kontribusi pasangan calon dalam ruang politik lokal. Hal inilah yang menyebabkan perbedaan yang sangat signifikan jumlah koalisi partai dan ideologi dalam satu pasangan calon, baik ditingkat provinsi, kabupaten, dan kota.

Pada konteks komunikasi, komunikasi politik merupakan aksesibilitas bagi para calon kepala daerah untuk melakukan komunikasi politik yang efektif dengan rakyat pemilih. Aksesbilitas 
politik akan melahirkan tingkat elektabilitas politik, yang pada akhirnya tingkat aksebilitas politik yang tinggi berpotensi besar akan melahirkan dukungan partai politik untuk meminang atau mendukung pasangan calon. Hal ini disebabkan partai politik maupun koalisi partai tidak menginginkan pasangan calon yang tidak mempunyai "nilai jual" karena dapat mempengaruhi suara partai pada Pemilu berikutnya baik pemilihan legislatif maupun pemilihan presiden, oleh karena itu partai politik biasanya melakukan mapping politik terhadap calon yang akan didukungnya yang berpotensi memenangkan Pilkada.

Untuk mengemas pesan politik dalam kampanye pemilu menjadi urusan yang sangat penting bagi partai politik dan calon yang maju bersamanya, agar makna pesan dapat diterima secara efektif oleh audiensnya

\section{Daftar Pustaka}

Nimmo, Dan. 2004. Komunikasi Politik, Khalayak dan Efek. Jakarta: Rosdakarya.

Cangara, Hafied. 2009. Komunikasi Politik (Konsep, Teori, Strategi). Jakarta: Rajawali Press.

Abdullah, Zein. 2008. Strategi Komunikasi Politik dan Penerapannya. Bandung: Simbiosa.

Hkikmat, Mahi, M. 2017. KAPANYE JITU DALAM PILKADA: Perspektif Komunikasi Politik Pada Masyarakat Jawa Barat. Bandung: Jaringan Masyarakat Peduli Demokrasi.

Sulaiman, Adhi Iman. Komunikasi Politik dalam Demokratisasi. Jurnal Dinamika Komunikasi Politik Menjelang Pemilu 2014. Vol. 11, Nomor 2, Tahun 2013, BPPKI Bandung. 
Surya Kusuma dan Yon Hotman. 2008. Panduan Sukses Kampanye Pemilu 2009. Jakarta: Pustaka Cendekia Muda.

https://nasional.kompas.com/read/2018/06/23/21473321/infografi k-fakta-seputar-pilkada-serentak-2018. Diakses tanggal 8/7/2018 jam 16.15 .

Costas Panagopoulos Rutgers .Politicking Online, The Transformation of Election

Campaign Communications, University Press New Brunswick, New Jersey, And London

Dwi Elsa Wahyuni, Komunikasi Politik Calon Walikota Petahana Dr.H.Firdaus, St, $M t$

Dalam Kampanye Pemilihan Kepala Daerah Walikota Pekanbaru 2017-2022 Jom Fisip Vol. 5 No. 1 - April 2018

Eko Harry Susanto .Dinamika Komunikasi Politik Dalam Pemilihan Umum Jurnal Kajian Komunikasi, Volume 1, No. 2, Desember 2013 hlm 163-172

Darren G. Lilleker. Political Campaigning and Communication. Bournemouth University Bournemouth, Dorset, UK

Shoko Kiyohara - Kazuhiro Maeshima Diana Owen. Internet Election Campaigns in the United States, Japan, South Korea, and Taiwan. Palgrave Macmillan 